\title{
THYROTOXIC PERIODIC PARALYSIS: DIAGNOSIS, MANAGEMENT AND ROLE OF PROPRANOLOL IN TREATMENT
}

\author{
Jehan Saeed", Ayman Fathy", Ayman Abd-Elrahman M.N.", Osama Al Azoni*" \\ "Department of Internal Medicine, ${ }^{* *}$ Department of Neurology, Zagazig University
}

\section{ABSTRACT}

Background: Hypokalemia is commonly encountered during paralysis in patients with thyrotoxic periodic paralysis (TPP) and may contribute to neuromuscular manifestations. This condition mainly affects male patients of Asian descent. With increasing population mobility and admixture, TPP as the presenting feature of hyperthyroidism is more common in Western countries and Gulf area. TPP is an alarming and potentially lethal complication of hyperthyroidism characterized by muscle paralysis and hypokalemia due to a massive intracellular shift of potassium. A potassium supplement has been recommended to hasten recovery and prevent cardiopulmonary complications. However, this recommendation has not yet proven efficacious. Hyperadrenergic activity has been implicated in the pathogenesis of TPP. We tested whether nonselective $\beta$ blockers could terminate neuromuscular symptoms rapidly while reducing an intracellular shift of potassium. Methods: We describe 7 patients who had an acute attack of TPP with characteristic hypokalemia. Results: After oral propranolol, $3 \mathrm{mg} / \mathrm{kg}$, serum potassium concentrations increased promptly in all patients, and there was complete amelioration of paralysis. Only 3 patient needed short term K supplement for their sever hypokalemia and sever symptoms. No rebound hyperkalemia was detected. Conclusion: Given propranolol efficacy in this study, propranolol should be considered as a first-line therapy for TPP.

Key words: Hypokalemia, TPP, hyperthyroidism, propranolol, periodic paralysis

\section{INTRODUCTION}

\section{$\mathbf{T}$} HYROTOXIC PERIODIC PARALYSIS (TPP) is an alarming and potentially lethal complication of hyperthyroidism characterized by muscle paralysis and hypokalemia due to a massive intracellular shift of potassium. This condition mainly affects male patients of Asian descent. Many affected patients do not have obvious symptoms and signs of hyperthyroidism. Because the condition is rare in Caucasians, it is frequently overlooked and misdiagnosed on presentation. With increasing population mobility and admixture, TPP as the presenting feature of hyperthyroidism is more common in Western countries and Gulf area. Immediate therapy can prevent serious cardiopulmonary complications and may hasten recovery of the periodic paralysis. Effective control of hyperthyroidism is indicated to prevent the recurrence of paralysis ${ }^{(1)}$. TPP is a well-known complication of thyrotoxicosis in Asian populations, including Chinese, Japanese, Vietnamese, Filipino, and Koreans. The overall incidence of TPP in Chinese and Japanese thyrotoxic patients is 1.8 and $1.9 \%$, respectively ${ }^{(2)}$. In North America, the incidence rate of TPP was reported to be around $0.1-0.2 \%$ in thyrotoxic patients $^{(3,4)}$. Sporadic cases of TPP have also been reported in other non-Asian populations such as Caucasians, Afro-Americans, American Indians, and Hispanics. The American Indians are thought to be at a higher risk of TPP because there is evidence that their ancestors originated in Asia and migrated to North America between 11,000 and 23,000 years ago $^{(5,6)}$. Despite a much higher incidence of thyrotoxicosis in women, TPP predominantly affects males. In the Chinese, TPP occurs in $13 \%$ of male and $0.17 \%$ of female thyrotoxic patients, in a series published in $1967^{(1)}$, whereas in the Japanese, the incidence was 8.67 among male and $0.4 \%$ among female thyrotoxic patients in $1957^{(2)}$. Overall, the male to female ratio ranges from $17: 1$ to $70: 1^{(1,2,7,8)}$. Patients with TPP usually experience the attack a few hours after a heavy meal or in the early morning upon waking: more than two thirds of patients present to the emergency department between 2100 and $0900 \mathrm{~h}$. Such timing of presentation led the condition to be initially described as nocturnal paralysis or night palsy ${ }^{(9,22)}$. Patients may give a history of similar but milder attacks before presentation. Attacks are commonly precipitated by ingestion of carbohydrate-rich meals or sweet snacks, alcohol, or strenuous exercise. In these patients the paralysis can be induced by a high glucose load, insulin infusion, and exercise test. The weakness does not occur during exercise but during the resting period after exercise and may be aborted by resumption of the exercise. In subtropical regions, a seasonal variation is observed that is probably related to increase outdoor exercise or consumption of sweet drinks during summer. TPP occurs only in the presence of hyperthyroidism and 
is abolished when thyroid hormone levels are normalized $^{(10)}$.

\section{PATIENTS \& METHODS}

Follow up outcome of cases of TPP diagnosed and treated in Internal Medicine Department in $\mathrm{Al}$ Ameen Hospital in Al Taif KSA during 2011 and 2012. Seven patients were diagnosed in Al Ameen Hospital in Al Taif in KSA over 2 years. Patients were seen in our emergency department in the early hours of the morning with a dramatic onset of weakness and paralysis. Their ages ranged from 21 to 42 years. Four patients were Filipino ( 2 males and 2 females), and two patients were Chinese (males), one patient was Indian male (see table 1). They had presented between the hours of 12 am to 10 am by ambulance to our emergency department. All seven patients had gone to bed the night before asymptomatic. None of them had any past history or family history of renal disease known. All were also asked specifically for a history of thyroid disorders, but none had such problems before. None of them had recent viral infections, or ingestion of canned foods. Physical examination of the patients revealed a similar pattern of proximal muscle weakness in all, affecting mainly the muscles of the back and the shoulder and pelvic girdles. Deep tendon reflexes were absent in all the patients. Four of the patients also had complaints of aching pains in the muscles of their back, shoulders and thighs. No sensory loss was found in all. All of them had intact cranial nerve functions, without dysphagia, stridor or loss of voice. There were also no cardiac arrhythmias on cardiac monitoring, and they did not have respiratory difficulties. No sphincter incontinence of both bowel and bladder were noted. An examination for symptoms and signs of thyroid overactivity were also carried out in the patients. There were symptoms of weight loss and heat intolerance in patients 2, 4 and 6, but the others had no history of weight loss, heat intolerance, sweaty palms or symptoms indicative of hyperthyroidism. No palpable goitre was found clinically in 1 and 5 patients, but patients 2 and 3 had thyroid nodule. Other patients had diffuse thyroid swelling. In patients 2, 4 and 6 mild exophthalmos and lid lag signs, indicative of Graves' disease.

\section{RESULTS}

Our patients were (2 Chinese patients, 4 Filipino patients and 1 Indian patient), 2 females and 5 males. The flaccid paralysis involved predominantly the muscles of the back, and of the shoulder and pelvic girdles. Proximal muscles were more severely affected than the distal muscles. There was no involvement of the sensory system, and mental function was intact in all. There was sparing of the cranial nerves, bulbar, ocular and respiratory muscles. Deep tendon reflexes were lost, but the anal sphincter tones were preserved, as were urinary continence. All the patients were found to have hypokalemia, ranging from 1.7 to $2.6 \mathrm{mmol} / \mathrm{l}$. There were no sodium or chloride abnormalities. Thyroid function tests confirmed thyrotoxicosis in all cases, with an increase of free thyroxine (T4) levels and suppression of thyroid stimulating hormone levels. All the patients were admitted to the hospital for further treatment oral propranolol $3 \mathrm{mg} / \mathrm{kg}$ plus carbimazole 30-60 mg/day. Intravenous (i.v) $\mathrm{KCl}$ $10 \mathrm{mmol} /$ hour given to the patients 2,4 and 7 till $\mathrm{K}$ level increased to more than $2.5 \mathrm{mmol} / \mathrm{l}$. They were all discharged within a week with antithyroid medications, as well as with oral propranolol tablets. An oral potassium supplement was not given but advice of $\mathrm{K}$ rich diet. After oral propranolol, $3 \mathrm{mg} / \mathrm{kg}$, serum potassium concentrations increased promptly in all patients, and there was complete amelioration of paralysis. No rebound hyperkalemia was detected. Only 3 patients needed i.v $\mathrm{KCl}$ supplement. 
Table 1 Features of patients presenting with thyrotoxic periodic paralysis

\begin{tabular}{|c|c|c|c|c|c|c|c|c|}
\hline $\mathrm{N}$ & $\begin{array}{l}\text { Age/sex/rac } \\
e\end{array}$ & $\begin{array}{l}\text { Initial } \\
\text { s. K } \\
(\mathrm{mmol} \\
/ \mathrm{l}) * \\
\end{array}$ & $\begin{array}{l}\mathrm{F} 4 \\
\text { (pmol/ } \\
\text { l) } *\end{array}$ & $\begin{array}{l}\text { TSH } \\
(\mathrm{mU} / \mathrm{l}) \\
*\end{array}$ & $\begin{array}{l}\text { Diagnosis of } \\
\text { hyperthyroidi } \\
\text { sm }\end{array}$ & $\begin{array}{l}\text { Symptoms } \\
\text { and signs of } \\
\text { thyrotoxicosi } \\
\mathrm{s}\end{array}$ & $\begin{array}{l}\text { Recurrence } \\
\mathrm{s} \text { of TTP }\end{array}$ & $\begin{array}{l}\text { Aetiology of } \\
\text { thyrotoxicosi } \\
\text { s }\end{array}$ \\
\hline 1 & $\begin{array}{l}\text { 33/F/Filipin } \\
\text { o }\end{array}$ & 2.4 & 35.85 & $<0.001$ & $\begin{array}{l}\text { Not known } \\
\text { thyrotoxic } \\
\text { before, } \\
\text { thyroid tests } \\
\text { was normal in } \\
\text { her country }\end{array}$ & Not present & $\begin{array}{l}2 \text { episodes } \\
1 \text { st one } \\
\text { year before } \\
\text { diagnosis }\end{array}$ & $\begin{array}{l}\text { Graves' } \\
\text { disease }\end{array}$ \\
\hline 2 & $\begin{array}{l}\text { 42/M/Filipin } \\
\text { o }\end{array}$ & 1.8 & 53.27 & $<0.001$ & $\begin{array}{l}\text { Not known } \\
\text { thyrotoxic } \\
\text { before }\end{array}$ & Present & 1 episode & $\begin{array}{l}\text { Solitary toxic } \\
\text { adenoma }\end{array}$ \\
\hline 3 & 40/M/Indian & 2.3 & 37.84 & $<0.001$ & $\begin{array}{l}\text { Not known } \\
\text { thyrotoxic } \\
\text { before }\end{array}$ & Not present & 1 episode & $\begin{array}{l}\text { Solitary toxic } \\
\text { adenoma }\end{array}$ \\
\hline 4 & $\begin{array}{l}\text { 29/M/Filipin } \\
\text { o }\end{array}$ & 1.9 & 48.53 & $<0.001$ & $\begin{array}{l}\text { Not known } \\
\text { thyrotoxic } \\
\text { before }\end{array}$ & Present & 1 episode & $\begin{array}{l}\text { Graves' } \\
\text { disease }\end{array}$ \\
\hline 5 & $\begin{array}{l}\text { 21/M/Chine } \\
\text { se }\end{array}$ & 2.7 & 33.74 & $<0.001$ & $\begin{array}{l}\text { Not known } \\
\text { thyrotoxic } \\
\text { before }\end{array}$ & Not present & 1 episode & $\begin{array}{l}\text { Graves' } \\
\text { disease }\end{array}$ \\
\hline 6 & $\begin{array}{l}\text { 30/M/Filipin } \\
\text { o }\end{array}$ & 2.6 & 43.80 & $<0.001$ & $\begin{array}{l}\text { Not known } \\
\text { thyrotoxic } \\
\text { before }\end{array}$ & Present & 1 episode & $\begin{array}{l}\text { Graves' } \\
\text { disease }\end{array}$ \\
\hline 7 & $\begin{array}{l}\text { 33/F/Filipin } \\
\text { o }\end{array}$ & 1.7 & 40.22 & $<0.001$ & $\begin{array}{l}\text { Not known } \\
\text { thyrotoxic } \\
\text { before }\end{array}$ & Not present & 1 episode & $\begin{array}{l}\text { Graves' } \\
\text { disease }\end{array}$ \\
\hline
\end{tabular}

*Reference Range $\mathrm{s} \mathrm{K}=3.4-5.2 \mathrm{mmol} / \mathrm{l}, \mathrm{FT} 4=10.30-22.00 \mathrm{pmol} / \mathrm{l}$; $\mathrm{TSH}=0.5$ to $5.0 \mathrm{mU} / \mathrm{l}, \mathrm{F}=\mathrm{female}, \mathrm{M}=$ male

\section{DISCUSSION}

Thyrotoxic periodic paralysis has a predilection for afflicting Asian men, and less frequently women as seen in our patients: ( 2 Chinese patients, 4 Filipino patients and 1 Indian patient), 2 females patients and 5 males patients were a good indication of how Asian races are affected. The incidence of thyrotoxicosis is higher in females but thyrotoxic periodic paralysis is even lower in female thyrotoxic patients, but there are no reliable figures and no clear explanation for this predilection. Same predilection for afflicting Asian men has been described in $\operatorname{Japan}^{(11)}$, Singapore ${ }^{(12)}$, China ${ }^{(13)}$, and also has been recognized in Thai, Filipino, Vietnamese, Korean, and Malay populations. The presentations of our patients are typical and in a Singaporean Study ${ }^{(12)}$, patients experienced the onset of paralysis between $6 \mathrm{pm}-8$ am and in our patients were from $12 \mathrm{am}-10 \mathrm{am}$, this may be due to difference of lifestyle in KSA. In general, patients with TPP usually experience the attack a few hours after a heavy meal or in the early morning upon waking: more than two thirds of patients present to the emergency department between $9 \mathrm{pm}$ and $9 \mathrm{am}$. Such timing of presentation led the condition to be initially described as nocturnal paralysis or night palsy ${ }^{(9,22)}$.The flaccid paralysis involved predominantly the muscles of the back, and of the shoulder and pelvic girdles. Proximal muscles were more severely affected than the distal muscles. There was no involvement of the sensory system, and mental function was intact in all. There was sparing of the cranial nerves, bulbar, ocular and respiratory muscles. Deep tendon reflexes were lost, but the anal sphincter tones were preserved, as were urinary continence. These findings differentiate thyrotoxic periodic paralysis from Guillain-Barre syndrome, myasthenia gravis, botulism and transverse myelitis. The presence of hypokalemia will often suggest the diagnosis of thyrotoxic periodic paralysis to the emergency 
physician practising in Asia rather than familial periodic paralysis, and raised thyroid function tests will serve to confirm it and exclude familial periodic paralysis. In a previous study, McFadzean and Yeung ${ }^{(13)}$ found that the manifestations of the hyperthyroid state preceded the episodes of paralysis by three months to nine years in $80 \%$ of affected subjects. This seems to suggest that the thyrotoxicosis was usually very obvious at the time of presentation. However, four of our seven patients had no clinical signs or symptoms of thyrotoxicosis in the emergency department, and the diagnosis was found on thyroid function testing moreover one patient had an attack of TPP one year before diagnosis of thyrotoxicosis and thyroid tests were normal at that time from history taking. This case had no explanation because no previous cases diagnosed while they are euthyroid and as a rule: TPP occurs only in the presence of hyperthyroidism and is abolished when thyroid hormone levels are normalized ${ }^{(10)}$. As such, we have to now regard that hypokalemic periodic paralysis can be the initial manifestation of hyperthyroidism even it can preceed the diagnosis by one year as in our female Filipino patient, which had remained clinically "silent". The hypokalemia that occurs is not attributable to a depletion of body potassium stores. Rather, it is attributable to an intracellular shift of body potassium stores that is catecholamine mediated $^{(14,15)}$. Thyroid hormone increases the sodium/potassium-ATPase activity in skeletal muscle, liver, and kidney ${ }^{(16-18)}$. In hyperthyroidism, the resulting increase in inward shift of potassium thus causes periodic paralysis. Also, the diurnal variation in potassium movement where there is nocturnal potassium influx into skeletal muscle would explain the tendency for thyrotoxic periodic paralysis to occur at night ${ }^{(19)}$. Mcfadzean and Yeung have suggested that the severity of the hypokalaemia determines the severity of the weakness $^{(13)}$. The tendency for it to occur more in men than women is as yet unexplained. If left alone, the paralysis recovers over the next 36 hours as the potassium levels return to normal values as the potassium moves back out of the cells into the extracellular space. It can be hastened by potassium replacement, but as potassium is released from the cells into the circulation during the recovery phase of the paralytic attack, any aggressive potassium administration can cause a fatal "rebound" hyperkalemia, and there is less inclination now to replace potassium aggressively.
Non selective $\beta$-blockers reverse these abnormalities and resulted in rapid recovery of hypokalemia and paralysis without rebound effect. The definitive treatment is achievement of a euthyroid state. Though Graves' disease is the commonest etiology (as exemplified with five of our patients), thyrotoxic periodic paralysis can occur with hyperthyroidism from any cause ${ }^{(13,20)}$. Our patients recovered with propranolol mainly with use of $\mathrm{K} \mathrm{Cl}$ iv supplement in cases of sever hypokalemia less than $2 \mathrm{mmol} / \mathrm{l}$. Birkhahn et al ${ }^{(21)}$ also described a patient with thyrotoxic periodic paralysis who was given iv propranolol in large doses to counteract the peripheral effects of the thyrotoxicosis (hypertension, tachycardia). This had the dramatic effect of also reversing the thyrotoxic periodic paralysis. As one of the proposed mechanisms of hypokalemia in these patients is a catecholamine mediated intracellular influx of potassium, they believed that this mechanism may have been blocked by propranolol, thereby achieving faster resolution of symptoms without resorting to exogenous potassium.

\section{CONCLUSION}

TPP is a rare condition in non-Asians, and the diagnosis at initial presentation is often delayed because of the subtleness of the clinical features of thyrotoxicosis and the similarities of the paralysis with other more common conditions. With population mobility and admixture, TPP is becoming more common in Gulf area. Early diagnosis prevents serious cardiopulmonary complications. TPP is a curable disorder that resolves when a euthyroid status is achieved. Early morning weakness and paralysis with hypokalemia should suggest thyrotoxic periodic paralysis to the emergency physician caring for Asian patients. It can be the first manifestation of thyrotoxicosis in male patients who are otherwise asymptomatic. The definitive treatment is to render the patient euthyroid. The prophylactic use of potassium supplements does not seem to be successful in preventing such relapses. Nonselective $\beta$-blockers could terminate neuromuscular symptoms rapidly while reducing an intracellular shift of potassium and important in prevention of relapse in addition of its proven role in management of other symptoms of hyperthyroidism

\section{REFERENCES}

1. McFadzean AJS, Yeung R 1967 Periodic paralysis complicating thyrotoxicosis in Chinese. Br Med $\mathrm{J}$ $1: 451-455$ 
2. Okinaka S, Shizume K, Lino S, Watanabe A, Irie M, Noguchi A, Kuma S, Kuma K, Ito T 1957 The association of periodic paralysis and hyperthyroidism in Japan. J Clin Endocrinol Metab 17:1454-1459

3. Ober KP 1992 Thyrotoxic periodic paralysis in the United States. Report of 7 cases and review of the literature. Medicine 71:109-120

4. Kelley DE, Gharib H, Kennedy FP, Duda RJ, McManis MB 1989 Thyrotoxic periodic paralysis. Report of 10 cases and review of electromyographic findings. Arch Intern Med 149:2597-2600

5. Layzer RB 1990 Neuromuscular manifestation of endocrine disease. In: Becker KL, ed. Principles and practice of endocrinology and metabolism. Philadelphia: JB Lippincott; 1536

6. Wendorf M, Goldfine ID 1991 Archaeology of NIDDM. Excavation of the "thrifty" genotype. Diabetes 40:161-165

7. Tinker TD, Vannatta JB 1987 Thyrotoxic hypokalemic periodic paralysis: report of four cases and review of the literature. J Okla State Med Assoc 80:76-83 (Review)

8. Ko GTC, Chow CC, Yeung VTF, Chan HHL, Li JKY, Cockram CS 1996 Thyrotoxic periodic paralysis in a Chinese population. Q J Med 89:463468

9. Shizume K, Shishiba Y, Kuma K, Noguchi S, Tajiri J, Ito K, Noh JY 1992 Comparison of the incidence of association of periodic paralysis and hyperthyroidism in Japan in 1957 and 1991. Endocrinol Jpn 39:315-318

10.Ko GTC, Chow CC, Yeung VTF, Chan HHL, Li JKY, Cockram CS 1996 Thyrotoxic periodic paralysis in a Chinese population. Q J Med 89:463468

11. Okinaka S, Shizume K, Iino S, et al. The association of periodic paralysis and hyperthyroidism in Japan. $\mathbf{J}$ Clin Endocrinol Metab 1957;17:1454-9.
12. Yeo PPB, Lee KO, Cheah JS. Thyrotoxic periodic paralysis: a study of 51 patients. In: Proceedings of the Second Congress of the Association of Southeast Asian Nations (ASEAN) Federation of Endocrine Societies, 30 Nov-3 Dec,1983, Bangkok, Thailand.

13. McFadzean AJS, Yeung R. Periodic paralysis complicating thyrotoxicosis in Chinese. BMJ 1967;1:451-5.

14. Shizume K, Shishiba Y, Sakuma M, et al. Studies of electrolyte metabolism in idiopathic and thyrotoxic periodic paralysis. I. Arteriovenous differences of electrolytes during induced paralysis. Metabolism 1996;15:138-44.

15. Shizume K, Shishiba Y, Sakuma M, et al. Studies of electrolyte metabolism in idiopathic and thyrotoxic periodic paralysis. II. Total exchangeable sodium and potassium. Metabolism 1996;15:138-44.

16. Kjeldsen K, Norgaard A, Gotzsche CO, et al. Effect of thyroid function on number of sodium-potassium pumps in human skeletal muscle. Lancet 1984;ii:810 .

17. Layzer RB. Periodic paralysis and the sodiumpotassium. Ann Neurol 1982;11:547-52.

18. Chan A, Shinde R, Chow CC, et al. In vivo and in vitro sodium pump activity in subjects with thyrotoxic periodic paralysis. BMJ 1991;303:10969.

19. Charness ME, Johns RJ. Hypokalemic periodic paralysis. Johns Hopkins Med J 1978;143:148-53.

20. Norris FH Jr, Clark EC, Biglieri EG. Studies in thyrotoxic periodic paralysis. J Neurol Sci 1972;13:431-42.

21. Birkhahn RH, Gaeta TJ, Melniker L. Thyrotoxic periodic paralysis and intravenous propranolol in the emergency setting. J Emerg Med 2000;18:199-202.

22. Talbott JH 1941 Periodic paralysis. Medicine 20:85-142. 


\section{الثلل الدوري الناتج عن فرط نثاط الغدة الدرقية: التشخيص والعلاج ودور عقار البروبرانولول}

الخلفية: نقص البوتاسيوم من العلامات المميزة للثلل الناتج عن فرط نشاط الغدة الدرقية و نقص البوتاسيوم المسبب لحدوث الثاث الثلل في هذه

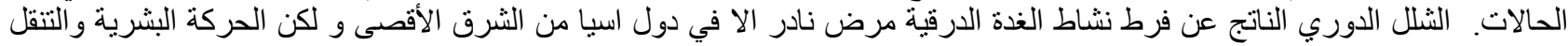

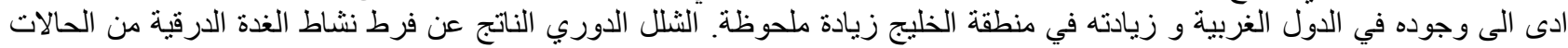

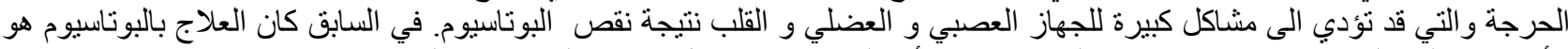

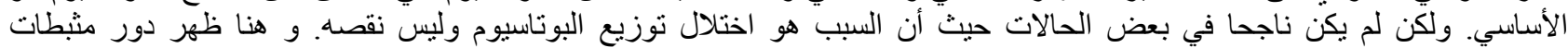

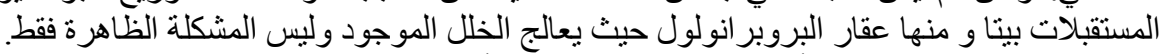

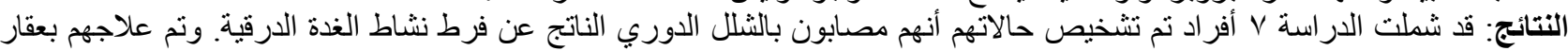

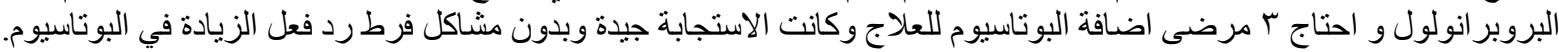

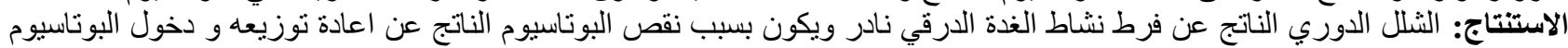

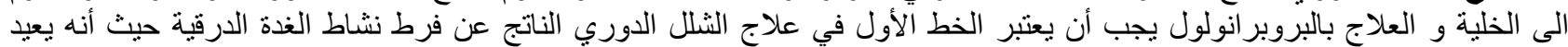
الأمور الى نصابها. 